\title{
Farm Business Feasibility of Pineapple Commodity after Volcanic Eruption in Ngancar District, Kediri, East Java Province
}

\author{
Risdiana Himmati ${ }^{\bowtie}$, Yunastiti Purwaningsih, Agustinus Suryantoro \\ Economics and Business Faculty, Sebelas Maret University, Surakarta, Central Java, Indonesia \\ e-mail: Risdiaana@gmail.com
}

\begin{abstract}
This study aims to find and analyze the effect of the input factors of activities undertaken in farm businesses affected by a volcanic eruption on their farm business. This research concentrates on the feasibility of the planted commodity whether it can still be continued with the feasibility value based on the results of the $R / C$ Ratio calculation or not. This study took place in a district located closest and suffered major damage due to the eruption of Mount Kelud in Ngancar District, Kediri Regency, East Java Province. This research used primary and secondary data. This study used the R/C Ratio method to analyze the feasibility of pineapple farm business in the Ngancar District, Kediri Regency. The results of the feasibility analysis of the pineapple farm business using the $R / C$ Ratio show that the pineapple farm business is financially feasible after the eruption of Mount Kelud because it has an $R / C$ ratio more than one.
\end{abstract}

Keywords: Pineapple, R/C Ratio, Mount Kelud

\begin{abstract}
Abstrak
Penelitian ini bertujuan untuk mengetahui dan menganalisis pengaruh faktor input kegiatan usaha tani yang terkena dampak letusan gunung berapi terhadap usaha tani. Penelitian ini berkonsentrasi pada kelayakan komoditas yang ditanam apakah masih dapat dilanjutkan dengan nilai kelayakan berdasarkan hasil perhitungan R/C Ratio atau tidak. Penelitian ini dilakukan di sebuah kabupaten yang letaknya paling dekat dan mengalami kerusakan parah akibat erupsi Gunung Kelud di Kecamatan Ngancar, Kabupaten Kediri, Provinsi Jawa Timur. Penelitian ini menggunakan data primer dan sekunder. Penelitian ini menggunakan metode R/C Ratio untuk menganalisis kelayakan usaha-usaha tani nanas di Kecamatan Ngancar Kabupaten Kediri. Hasil analisis kelayakan usaha tani nanas dengan R/C Ratio menunjukkan bahwa usaha tani nanas layak secara finansial pasca erupsi Gunung Kelud karena memiliki R/C ratio lebih besar dari satu.
\end{abstract}

Kata kunci: Nanas, Rasio R/C, Gunung Kelud 


\section{INTRODUCTION}

Mount Kelud is one of the most active volcanoes in Indonesia located in the Kediri Regency. The slopes of Mount Kelud itself stretches on three regencies, namely Kediri Regency, Blitar Regency, and Malang Regency. Mount Kelud is listed as the most active volcano, the last eruption of Mount Kelud was recorded on February 16 $6^{\text {th }}, 2014$. The volcano, which has a height of 1,731 meters above sea level, erupted explosively. About 150 million cubic meters of volcanic materials consisting of ash, sand, and rocks burst from the bowels of the volcano. Incandescent lava ejected as high as 17 kilometers. The high ejection of eruption materials was correlated with the extent distribution of the ash fall so that it covered almost all parts of Java (Auliani, 2014).

The eruption that occurred in 2014 resulted in several damages that accounted for a large amount of damage. The impact of the eruption of Mount Kelud not only resulted in tens of thousands of people evacuated and lost their homes and property, but also the loss of livelihoods due to the negative impact of volcanic materials which also destroyed residents' rice fields and agricultural lands. One of the most severe and very detrimental damage was the damage to agricultural lands, houses, and access roads covered by volcanic sand and ash. According to the entire UPT (Technical Implementation Unit Indonesian Legumes and Tuber Crops Research Institute or ILETRI) in East Java which had conducted previous research to determine the number of agriculture affected by the eruption in 2014 , they reported that agricultural businesses that were most affected by the eruption and suffered large losses were located in two districts. Puncu and Ngancar districts were the two districts most affected by the Kelud eruption. However, from several East Java Balitkabi monitorings, Ngancar District was the district in the territory of Kediri Regency with most villages experiencing the effects of Kelud eruption and the most damage to agricultural land.

Based on the conditions due to volcanic ash caused by the eruption of Kelud, of course not only infrastructures that were severely affected, but agriculture was also the most severely affected. Wulandari (2014) previously examined the impact of the eruption of Merapi on the income of salak nglumut farmers in Kaliurang Village, Srumbung District, Magelang Regency in 2009. The analytical tool used is the significance difference test to see differences in productivity before and after the eruption of Merapi. The results showed that there were differences in the income of salak nglumut farmers before the eruption and after the eruption. Comparison of the total revenue with the total cost for misplaced farming before the Merapi eruption, the R/C was 2.72 , while after the eruption, the $\mathrm{R} / \mathrm{C}$ was 1.73 .

Referring to research conducted by Nadiah (2014) entitled the impact of volcanic ash from the eruption of Mount Kelud, it states that volcanic ash matches sulfur or sulfur (S), aluminum (Al), and iron $(\mathrm{Fe})$, which will cause damage to the soil content which causes the acidity of the soil to increase (low $\mathrm{pH}$ ).

With the same characteristics, with the nature of an active volcano and high agricultural potential around Merapi, pineapple commodities that thrive into the main livelihoods of residents around Ngancar also influence the sustainability of the income of people living around Mount Kelud, especially residents of Ngancar District.

Siregar et al. (2015) also found that tomato farming in Gajah Village, Simpang Empat District, Karo Regency after the eruption of Mount Sinabung is feasible to be developed. The authors used the $\mathrm{R} / \mathrm{C}$ ratio to determine the feasibility from the financial aspect. The $\mathrm{R} / \mathrm{C}$ ratio was 3.67 . This means 
that every 1 rupiah of money spent can generate 3.67 rupiah of income.

On the other hand, Nainggolan et al. (2019) found that the eruption of Mount Karo led to an increase in the average production cost of carrot farming by $23.01 \%$ per farmer, an increase in the average production cost of chili farming to $63.60 \%$ per farmer, the average cost of producing tomato farming to increase to $79.86 \%$ per farmer. The eruption resulted in a decrease in the average income of cabbage farming by $18.34 \%$ per farmer, a decrease in the average income of tomato farming by $36.31 \%$ per farmer and a decrease in the average income of chili farming by $44.21 \%$ per farmer.

As explained in the Bank Indonesia's Regional Economic Review Report, which stated that Kelud eruption greatly affected the performance of the agricultural sector and other sectors, including its supporting sectors, namely the production and processing industries (Kajian Ekonomi Regional Bank Indonesia, 2014 Quarter I).

Ngancar District is the closest district to the eruption center of Mount Kelud with a distance of 5 kilometers from the summit of Mount Kelud. The short distance from the Mount Kelud peak resulted in more losses when the eruption occurred. Table 1 explains the area and agricultural commodities damaged by the eruption of Mount Kelud in the Ngancar District.

Table 1. Land area according to the commodity as the result of the eruption of Mount Kelud in Ngancar District, 2014

\begin{tabular}{cll}
\hline Number & Commodity & \multicolumn{1}{c}{$\begin{array}{c}\text { Area of Damaged } \\
\text { Land }\end{array}$} \\
\hline 1. & Pineapple & $2,449 \mathrm{Ha}$ \\
2. & Corn & $44 \mathrm{Ha}$ \\
3. & Chili Pepper & $27 \mathrm{Ha}$ \\
4. & Tomato & $26 \mathrm{Ha}$ \\
5. & Yardlong Bean & $4.5 \mathrm{Ha}$ \\
\hline
\end{tabular}

Source: Agriculture Agency of Kediri Regency, 2014
Pineapple is a horticulture commodity that has been cultivated by the government of the Kediri Regency for a long time and has high prospects and potential for continuous development. The increasing number of export demands for fresh pineapple encourages efforts to develop pineapple plants in the Ngancar District of Kediri Regency.

Agricultural activities will cease and will also greatly affect farmers' incomes. In this case, the role of the community and also the role of the government in its involvement to maintain the sustainability of economic and agricultural activities which are the foothold of the people in Puncu District are highly considered. Following the current situation that the eruption would cause farmers' income and farm business automatically changed, therefore this research needs to be conducted to look at the two years after the eruption of Mount Kelud on-farm business conditions, the feasibility of pineapple commodity which is the main commodity becoming the foothold of economic activity. This research will try to focus, find, and analyze the feasibility of Pineapple Commodity Farm Business in the Ngancar District after Mount Kelud Eruption. As a result of the eruption of Mount Kelud, all plants were covered with volcanic ash up to $10 \mathrm{~cm}$ thick so that the leaves became wilted and plants became hot which consequently failed to be harvested. Even some farmers who only had to wait for the time to harvest their pineapple were forced to harvest their pineapples that have been planted early in large quantities. So that the feasibility of post-eruption farm business needs to be done considering the large loss suffered by farmers.

Based on two years after the eruption of Mount Kelud, the development of Pineapple will greatly change as well as the development of the farmers. Agricultural activities will cease and will also greatly affect farmers' incomes. To narrow the 
problem and to formulate the main problem to see further the post-eruption conditions of the pineapple farm business.

Miller and Meiners (2000) state that the term production is defined as the use or utilization of resources that transform a commodity into another that is completely unequal or different from one another, both in terms of what and where or when those commodities are. Production is a flow concept, which means that production is an activity that is measured as levels of output per unit in a certain period. Meanwhile, the output itself is assumed to be of constant quality.

Production is the result of a process of economic activity by utilizing several inputs or inputs. Production is also related to how a resource is used or processed to produce a product. Modern production theory in this case adds technological elements as a form of input elements (Pindyck and Robert, 2007).

According to Soekartawi (2005), farm revenue is the multiplication of production obtained by the selling price. This formulation can be written as follows

$$
T R=Y \times P_{Y}
$$

where TR is total revenue in rupiah, $\mathrm{Y}$ is the amount of production obtained in a farm in $\mathrm{Kg} / \mathrm{seed}$, and $\mathrm{P}_{\mathrm{Y}}$ is the price of $\mathrm{Y}$ in rupiah.

Analysis of farm income can be done with two approaches, namely the net income approach and profit acceleration. To calculate net farm income, the following formula is used

$$
N R=T C-T R
$$

where NR is the net farm income and TC is the total explicit cost, both terms are in rupiah.

Farming profit is the difference between revenue minus all costs consisting of explicit costs and implicit costs, formulated as follows

$$
\Pi=T R-T C
$$

where TC is the sum of explicit and implicit costs.

$\mathrm{R} / \mathrm{C}$ or Return Cost Ratio is known as the ratio (nisbah) between revenues and costs. $\mathrm{R} / \mathrm{C}$ ratio aims to determine the level of profit of a business and from the profits obtained by using the $\mathrm{R} / \mathrm{C}$ ratio assessment criteria, it will be seen whether the business that is being run is experiencing a profit or is feasible to be developed. The $\mathrm{R} / \mathrm{C}$ ratio can be formulated mathematically as follows

$$
R / C=\frac{P_{Q} \times Q}{T F C+T V C}
$$

Where PQ is the price of output Q, Q is the output, TFC is the total of fixed costs, and TVC is the total of variable costs.

If the $\mathrm{R} / \mathrm{C}$ yield is more than one, the farming is profitable, whereas if the $\mathrm{R} / \mathrm{C}$ yield is equal to one, then the farm is said to be even or does not experience profit and loss. If the $\mathrm{R} / \mathrm{C}$ yield is less than one, the farm will suffer a loss (Suratiyah, 2008).

\section{RESEARCH METHOD}

This study used the survey method and the unit of analysis studied was pineapple farmers in the Ngancar District of Kediri Regency. With a focus of research on the feasibility of farm business. This research used primary data and secondary data. Primary data used included farm business production data, land area, number of seed used, amount of fertilizer used, amount of pesticide used, and number of labors, all were taken from pineapple farmer respondents. Secondary data used included farmer household data from the Badan Pusat Statistika (Central Bureau of Statistics )and related agencies. The target population in this study included all pineapple farmers in Ngancar District using data from the BP 2 (Agricultural Counseling Center) of 
Agricultural Counseling Agency of Ngancar District and BPS (Central Bureau of Statistics of Kediri Regency). In which the data obtained was data containing data related pineapple farmers throughout the Ngancar District.

The sampling technique in this study was a simple random sampling method based on the total population according to the Association of Pineapple Farmer Groups of Ngancar District, namely 220 farmers, and the number of respondents selected was 40 pineapple farmers or 40 farmers who were doing pineapple planting activities in Ngancar District.

Primary data was obtained using a survey method with a direct interview technique in the field with a question method guide. The data obtained were was then matched with information from the Agricultural Counseling Agency of Ngancar District. Paid laborers used by respondents with an owned land area of more than $0.5 \mathrm{Ha}$ were as many as 15 paid laborers. This information was obtained from the Agricultural Counseling Agency of Ngancar District, Kediri Regency.
This analysis was used to find out whether the pineapple farm business planted by Ngancar District farmers is financially feasible or not. According to, R/C or Return Cost Ratio is known as the comparison between revenue and cost. The $\mathrm{R} / \mathrm{C}$ ratio from Eq.(4) then can be formulated mathematically as follows

$R / C$ ratio $=\frac{T R}{T C}$

\section{RESULTS AND DISCUSSIONS}

Costs in the pineapple farm business, in this case, are divided into two, explicit cost and implicit cost. Explicit cost is all costs incurred in the production process, while the implicit cost is the input value owned by the farmers themselves involved in the production process. Explicit cost in this study includes seeds, cane molasses fertilizer, urea, pesticides, non-family labors, and indirect taxes (Land and Building Tax or PBB), and the implicit cost is family labors, land rent, depreciation, and bank loan interest.

Table 2. The Average Explicit and Implicit Costs of Pineapple Farm Business by Assuming the Average Land Area of $\mathbf{0 . 4 2 ~ H a * ~ i n ~ N g a n c a r ~ D i s t r i c t ~ o f ~ K e d i r i ~ R e g e n c y ~ i n ~} 2016$

\begin{tabular}{cllll}
\hline No & \multicolumn{1}{c}{ Description } & $\begin{array}{c}\text { Average Explicit Cost } \\
\text { (IDR) }\end{array}$ & $\begin{array}{c}\text { Average Implicit Cost } \\
\text { (IDR) }\end{array}$ & $\begin{array}{c}\text { Average Total Cost } \\
\text { (IDR) }\end{array}$ \\
\hline 1 & Land & $5,000,000$ & 125,000 & $5,125,000$ \\
2 & Seed & $8,560,000$ & $4,280,000$ & $12,840,000$ \\
3 & Cane Molasses Fertilizer & $1,415,950$ & - & $1,415,950$ \\
4 & Urea Fertilizer & $1,500,000$ & - & $1,500,000$ \\
5 & Pesticides & 187,500 & - & 187,500 \\
6 & Labor & $3,685,000$ & 995,000 & $4,680,000$ \\
7 & Tax & 21,200 & - & 21,200 \\
8 & Capital Interest & 105,000 & - & 105,000 \\
9 & Equipment Depreciation & - & 40,000 & 40,000 \\
\hline Total & $20,474,650$ & $5,440,000$ & $25,914,650$ \\
Average Production (units) & 49,697 & & \\
Average Income & $35,665,875$ & & \\
\hline
\end{tabular}

Notes : $* 0.42 \mathrm{Ha}$ is the average land area possessed by 40 farm business respondents

Source: Primary data analysis, processed in 2016 
The average total cost for pineapple farm business in Ngancar District in one planting-to-harvesting season or 18 months for one respondent was approximately IDR $25,914,650$. The most expense incurred in one season is the cost of purchasing seedlings, with an average expenditure to buy seedlings of IDR 12,840,000. Labor costs incurred by one respondent was IDR 4,680,000. The average area of land used for pineapple farm business in the Ngancar District was $0.42 \mathrm{Ha}$.

Table 3. Average Cost and Average Production per Hectares of Pineapple Farm Business in Ngancar District, Kediri Regency in 2016

\begin{tabular}{llllll}
\hline No & \multicolumn{1}{c}{ Description } & \multicolumn{2}{c}{ Average Input } & $\begin{array}{r}\text { Average Total Cost* } \\
\text { (IDR) }\end{array}$ & $\begin{array}{c}\text { Cost per Ha** } \\
\text { (IDR) }\end{array}$ \\
\hline 1 & Land & $\mathrm{m}^{2}$ & 4200 & $5,125,000$ & $12,197,500$ \\
2 & Seed & Seeds & 49,697 & $12,840,000$ & $30,559,200$ \\
3 & Cane Molasses Fertilizer & Drum & 50 & $1,415,950$ & $3,369,961$ \\
4 & Urea Fertilizer & $\mathrm{Kg}$ & 20 & $1,500,000$ & $3,570,000$ \\
5 & Pesticides & Lt & 2 & 187,500 & 446,250 \\
6 & Labor & Working days & 7,85 & $4,680,000$ & $11,138,400$ \\
6 & Tax & IDR & & 21,200 & 50,456 \\
7 & Capital Interest & IDR & & 105,000 & 249,900 \\
8 & Equipment Depreciation & & & 40,000 & 95,200 \\
\hline Total & & & & $25,914,650$ & $61,676,867$ \\
Average production (units) & & & 49,967 & 118,278 \\
Average income & & & $35,665,875$ & $84,884,782$ \\
\hline
\end{tabular}

Notes: * total cost by assuming the average land area of $0.42 \mathrm{Ha}$.

** Total cost with an assumption of $1 \mathrm{Ha}$ with a calculation of $10,000 \mathrm{~m}^{2}$ divided by the average area of land possessed by the respondents of $4200 \mathrm{~m}^{2}$.

Source: Questionaire Data, processed in 2016

The area of land cultivated by Ngancar pineapple farmers was less than 1 hectare or less than $1000 \mathrm{~m}^{2}, 34$ respondents paid laborers, 6 respondents used unpaid laborers, and 6 respondents used both of them (paid and unpaid laborers). Unpaid laborers are family laborers (children, wives, sons- or daughtersin-law, parents, and so on). The average area of land planted by pineapples by farmers was less than 1 hectare so that to be 1 hectare it must be multiplied by 2.38 . Pineapple farm business with an area of 1 hectare in table 3 required an average cost of IDR 61,676,867, with the highest expenditure being on seed and labor costs.

The net income of the pineapple farm business in Ngancar District is derived from the difference between the revenue (total production value of the whole pineapple) minus the total explicit cost. It can be seen in Table 3 that the average income of Ngancar pine a pple far $\mathrm{m}$ ers is IDR 15,191,225. To $\mathrm{m}$ a ke it ea $\mathrm{s}$ ier in understanding the calculation, it will be presented as follows

$$
\begin{aligned}
& N R=T R-T C \\
& N R=I D R 35,665,875-I D R 20,474,650 \\
& N R=I D R 15,191,225
\end{aligned}
$$

The profit of the pineapple farm business is obtained from the difference between the total revenue (total production value of the whole pineapple) minus the total cost (the sum of the explicit and implicit costs). To better understand how the 
calculation of the average revenue value of pineapple farm business, the calculation will be explained as follows

$\Pi=T R-T C$

IDR35,665,875 - IDR25,914,650

$\Pi=I D R 9,751,225$

From the calculation of revenue and profit, it was found that the average value of pineapple farm business farmer income was greater when compared with the value of the profit obtained. The large revenue value was caused by the factors of production that are owned by many individuals, such as land, seeds, and labor. So that expenditure, in this case, does not become much of a problem plus the harvest period is relatively short or about 18 months.

It is not only those factors influencing the high revenue generated by pineapple farm business, but also farmers' planting method which not only relies on one land that has been planted but the strategy of farmers who have a cropping and harvesting patterns, such as harvesting on other lands and then waiting for another land then planting in other lands again.

The feasibility of the pineapple farm business was analyzed by using the $\mathrm{R} / \mathrm{C}$ (return cost ratio) method. This $\mathrm{R} / \mathrm{C}$ analysis was done by comparing the value of total revenue with the value of total cost. In this study, the analysis of the $\mathrm{R} / \mathrm{C}$ ratio is divided into two, namely the $\mathrm{R} / \mathrm{C}$ for explicit cost and $\mathrm{R} / \mathrm{C}$ for the total cost. To see the calculation of $\mathrm{R} / \mathrm{C}$ value, we calculate both $\mathrm{R} / \mathrm{C}$ ratio for explicit costs and for total costs.

For the $\mathrm{R} / \mathrm{C}$ ratio for explicit costs, we found a ratio of 1.74 . This result is obtained by dividing the TR of IDR $35,665,875$ by the total explicit costs of IDR20,474,650. For the $\mathrm{R} / \mathrm{C}$ ratio for total costs, we found a ratio of 1.37 by dividing the TR of IDR $35,665,875$ by the total explicit costs of IDR25,914,650
The calculation results obtained $\mathrm{R} / \mathrm{C}$ value for the explicit costs of 1.74 or greater than 1 so that the pineapple farm business in Ngancar District is feasible to be continued to become a more developed farm business. As for the $\mathrm{R} / \mathrm{C}$ value for the total costs is 1.37 or greater than 1 . This further confirms that the pineapple farm business in Ngancar District is very feasible to be developed and profitable because the $\mathrm{R} / \mathrm{C}$ values are greater than 1 .

\section{CONCLUSION AND RECOMMENDA- TION}

Based on the results of research on pineapple farm business in the Ngancar District, it can be concluded that the pineapple farm business in Ngancar District, Kediri Regency is financially feasible, because it is profitable with an $\mathrm{R} / \mathrm{C}$ value of bigger than one. The pineapple farm business needs attention from the government to be further developed so that Ngancar District is not only known as the Mount Kelud tourist route but also pineapple orchard tours which are highly cultivated by pineapple farmers so that the benefits for farmers and the government go in harmony with the development and introduction of large pineapple farming areas. Given the quality of pineapple from the Ngancar District is good with a very fertile fertility rate.

\section{REFERENCES}

Agriculture Agency of Kediri Regency, 2014.

Auliani, P. A. 2014. Gunung Kelud, Sejarah Panjang dan Anomali Letusan. Regional. www.regional.kompas. com, accessed on July 16 $6^{\text {th }}, 2016$.

BPS. 2012. Kecamatan Ngancar Dalam Angka. Central Bureau of Statistics: Kediri Regency. 
BPS. 2015. Kabupaten Kediri Dalam Angka. Central Bureau of Statistics: Kediri Regency.

BPS. 2015. Kecamatan Ngancar Dalam Angka. Central Bureau of Statistics: Kediri Regency

Kajian Ekonomi Regional Provinsi Jawa Timur Tw I. 2014. Jakarta: Bank Indonesia.

Miller, R. L. R., dan Meiners, R. E. 2001. Teori Ekonomi Intermediate, edisi ketiga. Jakarta: Raja Grafindo Persada.

Nadiah, A. 2014. Dampak Abu Vulkanik Hasil Erupsi Gunung Kelud terhadap Komoditas Perkebunan di Kabupaten Blitar. Surabaya: Balai Besar Perbenihan dan Proteksi Tanaman Perkebunan

Nainggolan, H. L. 2019. Dampak Erupsi Gunung Sinabung terhadap Kondisi Sosial Ekonomi Petani Hortikultura di Kabupaten Karo. Sosiohumaniora. Vol. 21(3), 287-295.
Pindyck, R. S., dan Rubinfeld, D. L. 2007. Mikroekonomi. Edisi 6 Jilid 1. Jakarta: Indeks.

Siregar, C. R., Darus, H. M. B., \& Hidayati, S. K. 2015. Analisis Usaha Tani Tomat Pasca Erupsi Gunung Sinabung (Studi Kasus: Desa Gajah, Kecamatan Simpang Empat, Kabupaten Karo). Journal on Social Economic of Agriculture and Agribusiness. Vol. 3(7).

Soekartawi. 2005. Teori Ekonomi Produksi: Dengan Pokok Bahasan Analisis Fungsi Cobb-Douglas. Jakarta: Rajawali Press.

Suratiyah, K. 2008. Ilmu Usahatani. Jakarta: Penebar Swadaya.

Wulandari, T. 2014. Dampak Erupsi Merapi terhadap Pendapatan Petani Salak Nglumut di Desa Kaliurang Kecamatan Srumbung Kabupaten Magelang Tahun 20092011. Economics Development Analysis Journal. Vol. 3)3). 